\title{
Effect of Ensiling Broiler Litter with Fermented Milk as I noculant
}

\author{
Sreehari S.* and R. K. Sharma \\ Department of Livestock Production and Management \\ CCS Haryana Agricultural University, Hisar 125 004, India \\ * Corresponding author
}

\begin{abstract}
Litter material was obtained from broiler birds, reared on chaffed straws of wheat (T1 to T4) and paddy (T5 to T8) at floor spaces of $0.15 \mathrm{sq} . \mathrm{m} / \mathrm{bird}$ (T1, T2, T5 \& T6) and 0.18sq.m/bird (T3, T4, T7 \& T8). The litter material was then mixed with $10 \%$ molasses (DMB).The treatment groups (T2, T4, T6 \& T8) were inoculated by $1 \%(\mathrm{v} / \mathrm{w})$ fermented milk on fresh weight basis whereas control groups (T1, T3, T5 \& T7) were not inoculated. All the stacks were covered with polythene sheet and ensiled for 21 days. Pooled over values of crude protein in the control groups, where fermented milk was not added, averaged $24.71 \%$ before ensiling and it reduced to $20.57 \%$ after ensiling. The corresponding values in the treatment groups, where fermented milk was added, were 24.76 and $21.31 \%$, respectively, indicating significantly $(\mathrm{P}<0.05)$ lesser losses of crude protein when ensiled with fermented milk. The $\mathrm{pH}$ of silage reduced from 7.6 to 6.0 in control group, whereas it reduced from 7.8 to 5.6 in the stacks in which fermented milk was added. Reduction in $\mathrm{pH}$ of silage is due to higher production of volatile fatty acids in the ensiled material inoculated by fermented milk, thereby indicating beneficial effect of fermented milk in silage making.

Key words: Broiler litter, Paddy straw, Wheat straw, Silage inoculation, Fermented milk.
\end{abstract}

\section{Introduction}

Poultry litter has a potential use as a ruminant feed in addition to its traditional use as fertilizer. In fact, the economic value of poultry litter as a feed ingredient in balanced diets for several classes of ruminants is up to four times greater than its value as a fertilizer (Jacob et al., 1997). In addition to offering an economic advantage, use of poultry litter as animal feed is environmentally friendly. The dramatic growth of the poultry industry created a serious waste disposal problem. The utilization of the waste through ruminant animals became a convenient option of disposing of the waste. Extension research should be done to elucidate the benefits of using poultry litter as ruminant feed rather than a fertilizer and so that possible contamination of underground water is minimized. Farmers should also be encouraged to explore deep stacked broiler litter as a feasible method of waste management and develop their own complementary system of animal production i.e. recycling of processed litter as ruminant feed (Talib and Ahmed, 2008). Bacterial inoculants are the most common type of silage additives. They are used to enhance the ensiling process and have been reported to occasionally result in improvements in animal performance (Muck, 1993; McAllister et al., 1998).

Most products include one or more homofermentative lactic acid bacterial (LAB) species. Pediococcus, Lactobacillus and Enterococcus species are most common bacteria that are included in the silage inoculants (Muck and Kung, 1997). Muck and Kung (1997) reported that microbial inoculant should apply at least 90 million $(9 \times 1010)$ live bacteria/ton $(9 \times 104 / \mathrm{g})$ fresh crop to be able to out-compete the epiphytic populations of lactic bacteria, and thereby to have a significant impact on the ensiling process. Dewan and Tamang (2007) reported that in the samples of ethnic fermented milk products like dahi, mohi, chhurpi, somar, philu and shyow, collected from different places of India, Nepal and Bhutan, the population of LAB ranged from 107 to $108 \mathrm{cfu} / \mathrm{g}$. In their study the dominant lactic acid bacteria were identified as Lactobacillus bifermentans, Lactobacillus paracasei sub-species pseudoplantarum, Lactobacillus kefir, Lactobacillus hilgardii, Lactobacillus alimentarius, Lactobacillus paracasei sub-species paracasei, Lactobacillus plantarum, Lactococcus lactis sub-species lactis, Lactococcus lactis sub-species cremoris and Enterococcus faecium.

\section{Material and Methods}

Two hundred and forty, day-old commercial broiler, chicks randomly allotted to four treatments, having four replicates of 15 birds each, were reared for six weeks. Fresh and dry wheat straw (T1 and T2) and paddy straw (T3 and T4) was used as litter material @ $5.5 \mathrm{Kg} / \mathrm{sq} \mathrm{m}$ in all treatments. Birds were grown at a 
Effect of Ensiling Broiler Litter with Fermented Milk as Inoculant

\begin{tabular}{|c|c|c|c|c|c|c|}
\hline Treatment & $\begin{array}{c}\text { Type of litter } \\
\text { (chaffed straw) }\end{array}$ & $\begin{array}{l}\text { Stocking density } \\
\text { (sq m/ bird) }\end{array}$ & Fermented milk* & DM & $\begin{array}{c}\text { CP } \\
\text { Day } 0\end{array}$ & $\begin{array}{c}\text { CP } \\
\text { Day } 21\end{array}$ \\
\hline T1 & Wheat & 0.15 & - & $60.04 \pm 0.07$ & $26.57 \mathrm{~b} \pm 0.06$ & $21.77 \mathrm{c} \pm 0.07$ \\
\hline T2 & Wheat & 0.15 & + & $59.93 \pm 0.07$ & $27.01 \mathrm{a} \pm 0.09$ & $23.11 \mathrm{a} \pm 0.11$ \\
\hline T3 & Wheat & 0.18 & - & $60.04 \pm 0.01$ & $26.32 \mathrm{c} \pm 0.09$ & $23.37 a \pm 0.17$ \\
\hline T4 & Wheat & 0.18 & + & $59.86 \pm 0.04$ & $25.96 \mathrm{~d} \pm 0.06$ & $22.54 \mathrm{~b} \pm 0.14$ \\
\hline T5 & Paddy & 0.15 & - & $60.13 \pm 0.03$ & $23.57 f \pm 0.09$ & $18.97 \mathrm{e} \pm 0.13$ \\
\hline T6 & Paddy & 0.15 & + & $59.85 \pm 0.01$ & $24.33 \mathrm{e} \pm 0.07$ & $21.13 \mathrm{~d} \pm 0.09$ \\
\hline T7 & Paddy & 0.18 & - & $59.97 \pm 0.07$ & $22.38 \mathrm{~g} \pm 0.08$ & $18.16 f \pm 0.09$ \\
\hline \multirow[t]{9}{*}{ T8 } & Paddy & 0.18 & + & $60.09 \pm 0.24$ & $\begin{array}{c}21.73 \mathrm{~h} \pm 0.09 \\
\text { Effect of litter type }\end{array}$ & $18.47 f \pm 0.6$ \\
\hline & Wheat & & & $59.97 \pm 0.03$ & $26.47 a \pm 0.12$ & $22.7 a \pm 0.19$ \\
\hline & Paddy & & & $60.01 \pm 0.06$ & $23.00 b \pm 0.31$ & $19.18 \mathrm{~b} \pm 0.35$ \\
\hline & & & & \multicolumn{3}{|c|}{ Effect of stocking density } \\
\hline & & 0.15 & & $59.99 \pm 0.04$ & $25.37 a \pm 0.44$ & $21.25 a \pm 0.45$ \\
\hline & & 0.18 & & $59.99 \pm 0.06$ & $24.09 b \pm 0.62$ & $20.64 b \pm 0.71$ \\
\hline & & & & \multicolumn{3}{|c|}{ Effect of fermented milk } \\
\hline & & & - & $60.05 \pm 0.03$ & $24.71 \pm 0.54$ & $20.57 b \pm 0.64$ \\
\hline & & & + & $59.93 \pm 0.06$ & $24.76 \pm 0.6$ & $21.31 a \pm 0.54$ \\
\hline
\end{tabular}

Means bearing different superscripts differ significantly $(P<0.05), *$ ' + ' denotes fermented milk was added

stocking density of $0.15 \mathrm{sq} \mathrm{m} / \mathrm{bird}$ in T1 and T4 and at a stocking density of $0.18 \mathrm{sq} \mathrm{m} / \mathrm{bird}$ in $\mathrm{T} 2$ and $\mathrm{T} 4$ by using pens of floor space of $2.25 \mathrm{sq} \mathrm{m}$ and $2.7 \mathrm{sq} \mathrm{m}$, respectively. Used litter after the disposal of birds from each treatment was collected and divided into two stacks each, thus giving a total of eight treatments (T1 to T8;). Molasses was added @ 10\% (w/w) on DM basis in all the treatments. In treatments T1 to T4 wheat straw was used as substrate while in treatment groups T5 to T8 paddy straw litter was used. Litter in treatments T1, T2, T5 and T6 was obtained from birds reared at a stocking density of $0.15 \mathrm{sq} \mathrm{m} / \mathrm{bird}$ and that of T3, T4, T7 and T8 was obtained from birds reared at a stocking density of $0.18 \mathrm{sq} \mathrm{m} / \mathrm{bird}$. Fermented milk was prepared by the traditional method (De, 2003) and added to four treatments T2, T4, T6 and T8 @ of $1 \%$ $(\mathrm{v} / \mathrm{w})$. The material was tightly packed to prevent aerobic fermentation and covered with polythene sheets for ensiling. The stacks were opened after 21 days of ensiling. Composite samples were drawn by mixing samples taken from different parts of the stack and the $\mathrm{pH}$ and proximate principles were estimated (AOAC, 2007). The data were analyzed statistically (Snedecor and Cochran, 1994).

\section{Results and Discussion}

Total dry matter losses during ensiling: The total dry matter (DM) content in the litter material in various treatments in kilograms were 63.04, 62.93, $63.04,62.85,62.84,63.14,62.98$ and 63.09 respectively, in treatments $\mathrm{T} 1$ to $\mathrm{T} 8$ at the beginning of the experiment. The corresponding values after 21 days of ensiling were 55.81, 55.60, 55.74, 55.85,
$55.47,55.73,55.67$ and 56.34 respectively. The highest loss of DM (11.74\%) was in T5, in which paddy straw litter of birds reared at floor space of 0.15 sq $\mathrm{m} / \mathrm{bird}$ was ensiled without addition of fermented milk. The lowest DM losses $(10.71 \%)$ were observed in litter of same material containing manure of birds reared at a lower stocking density $(0.18 \mathrm{sq} \mathrm{m} / \mathrm{bird})$ but to which fermented milk was added. The present findings are in agreement with those of Zahiroddini et al. (2006).

The DM losses observed in the present study $(10-11 \%)$ are higher than the values obtained by Yahaya et al. (2001) of 2 to $5 \%$, probably due to the difference in the material ensiled namely low density fodder like straw was used which is more prone to oxidative losses than succulent fodder like elephant grass. Contrary to the above findings, Gupta (1974) could not find any significant effect of inoculation of Lactobacilli on DM content when poor quality roughages were ensiled. The decreased losses of DM in silage, which was inoculated with lactobacilli, may be due to lesser hetro-fermentation occurring in it. The results of the present study indicate that inoculation of silage with lactobacilli decreases the DM losses during ensiling.

Crude protein composition of silage: Loss of about 13 to 20 per cent nitrogen in various treatments (Table-1) was comparatively higher than that (approximately $1 \%$ ) reported by Caswell et al. (1978) which may be due to the difference in silage material used (low density fodder). Higher oxidative losses could be anticipated due to increased permeability of air in low density fodders. The pooled over values showed that CP content of silages changed from 24.71 to $20.57 \%$ in treatments where fermented milk was not 
Effect of Ensiling Broiler Litter with Fermented Milk as Inoculant

\begin{tabular}{cccccc}
\hline \multicolumn{2}{l}{ Table-2. Mean pH of the litter material before and after ensiling } \\
\hline Treatment & $\begin{array}{c}\text { Type of litter } \\
\text { (chaffed straw) }\end{array}$ & $\begin{array}{c}\text { Stocking density } \\
\text { (sq m/ bird) }\end{array}$ & Fermented milk* & Day 1 & pH of litter \\
Day 21
\end{tabular}

Means bearing different superscripts differ significantly $(P<0.05), *$ ' + ' denotes fermented milk was added

added while the loss of protein was lesser (24.76 to $21.31 \%$ ) in treatments containing fermented milk. Slottner and Bertilsson (2006) reported significantly lesser proteolysis in inoculated silages compared to non-inoculated ones and attribute the reason to lesser breakdown of protein in silages with added cultures. pH of silage: Pooled over values indicated significantly $(\mathrm{P}<0.05)$ lower $\mathrm{pH}$ of 5.63 as a result of addition of fermented milk as compared to 6.01 in silage not treated with fermented milk (Table 2). The lowering of $\mathrm{pH}$ may be due to higher production of lactic acid in inoculated silages. Decreased $\mathrm{pH}$ values as a result of inoculation with lactic acid bacteria have also been recorded by other workers (Slottner and Bertilsson, 2006; Kwak et al., 2009) in similar studies.

Ensiling of litter material with fermented milk @ $1 \%(\mathrm{v} / \mathrm{w})$ on fresh weight basis is quite helpful in minimizing losses of nutrients during ensiling.

\section{Acknow ledgement}

The authors are thankful to the Dean, College of Animal Sciences, CCS Haryana Agricultural University for providing the facilities required for conducting the research work.

\section{References}

1. AOAC. (2007). Official Methods of Analysis. Association of official Analytical Chemists. $18^{\text {th }}$ edn. Gaithersburg, MD.

2. Caswell, L.F., et.al. (1978). Fermentation and utilization of broiler litter ensiled at different moisture levels. $J$. Anim.Sci. 46: 547-561.

3. De, S. (2003). Outlines of Dairy Technology. Oxford University Press, New Delhi.

4. Dewan, S. and J.P. Tamang. (2007). Dominant lactic acid bacteria and their technological properties isolated from the Himalayan ethnic fermented milk products. Antonie van Leeuwenhoek. 92:343-352.

5. Gupta, M.L.(1974). Improving the nutritive value of poor quality roughages through ensiling. Ph D Thesis. CCS Haryana Agric. Univ., Hisar, India.

6. Jacob, J.P., et.al.(1997). Broiler Litter. Part 1: A feed ingredient for ruminants. Institute of Food and Agricultural Science. Univ. of Florida Cooperative Extension Service.

7. Kwak, W.S., et.al. (2009). Molasses and Microbial Inoculants Improve Fermentability and Silage Quality of Cotton Waste-based Spent Mushroom Substrate. Bioresource Technology. 100: 1471-1473.

8. McAllister, T.A., et.al.(1998). Inoculants for alfalfa silage: Effects on aerobic stability, digestibility and the growth performance of feedlot steers. Livest. Prod. Sci. 53: 171-181.

9. Muck, R.E. (1993). The role of silage additives in making high quality silage. In: Proceedings of the National Silage Production Conference. Syncrause, NY, USA

10. Muck, R.E., and L. Kung Jr. (1997) Effects of silage additives on ensiling. In: Silage: Field to feed bunk. In: Proceedings of Proceedings of the North American Conference. Northeast Registered Agricultural Engineering Services Cooperative Extension, Hershey, Pennsylvania. pp. 187-199.

11. Slottner, D., and J. Bertilsson. (2006). Effect of ensiling technology on protein degradation during ensilage. Anim Feed Sci. Technol. 127: 101-111.

12. Snedecor, G.W. and W.G. Cochran. (1994). Statistical Methods. $8^{\text {th }}$ edn. Affiliated East-West Press, New Delhi.

13. Talib, N.H., and A.F. A. (2008). Performance and carcass characteristics of intact zebu bulls fed different levels of deep stacked poultry litter. J. Anim. Vet. Adv. 7: 1467-1473.

14. Weinberg, Z.G., and R.E. Muck. (1996). New trends and opportunities in the development and use of inoculants in silage. FEMS Microbiol. Rev. 19: 53-68.

15. Yahaya, M.S., et.al. (2001). Effect of length of ensiling on silo degradation and digestibility of structural carbohydrates of lucerne and orchardgrass. Anim. Feed Sci. Technol. 92: 141-148.

16. Zahiroddini, H.,et.al. (2006). Effect of microbial inoculants on the fermentation, nutrient retention and aerobic stability of barley silage.Asian-Aust. J.Anim. Sci. 19: 1429-1436. 